\title{
Clothed in Blessing: Meaning in Mesquakie Costume
}

\author{
Ruth B. PHILliPS
}

IN JULY 1837 an Englishwoman named Mrs. Anna Jameson visited Henry Schoolcraft and his Ojibwa wife Jane Johnston at the Indian agency at Macinaw, Michigan. She was deeply interested in the many Great Lakes Indians of different nations who stopped there that month to negotiate with the agent. The dress of one young Potawatomi man particularly impressed her.

His face was most artistically painted, the upper half of it being vermillion, with a black circle round one eye, and a white circle round the other; the lower half of a bright green, except the tip of his nose, which was also vermillion. His leggings of scarlet cloth were embroidered down the sides, and decorated with tufts of hair. The band, or garter, which confines the leggings, is always an especial bit of finery; and his were gorgeous, all embroidered with gay beads, and strings and tassels of the liveliest colours hanging down to his ankle. His moccasins were also beautifully worked with porcupine quills; he had armlets and bracelets of silver, and round his head a silver band stuck with tufts of moosehair, dyed blue and red; and conspicuous above all, the eagle feather, in his hair, showing he was a warrior, and had taken a scalp.... Over his shoulders hung a blanket of scarlet cloth, very long and ample, which he had thrown back a little, so as to display his chest, on which a large outspread hand was painted in white. ${ }^{1}$

This essay is a revised version of a talk presented to the Symposium on Mesquakie Art and Culture held at the University of Iowa Museum of Art, 28 January 1989.

1. Anna Jameson, Winter Studies and Summer Rambles in Canada, ed. James J. Talman and Elsie McLeod Murray (Toronto, 1943), 169.

THE ANNALS OF IOWA 51 (Summer 1991). CThe State Historical Society of Iowa, 1991. 


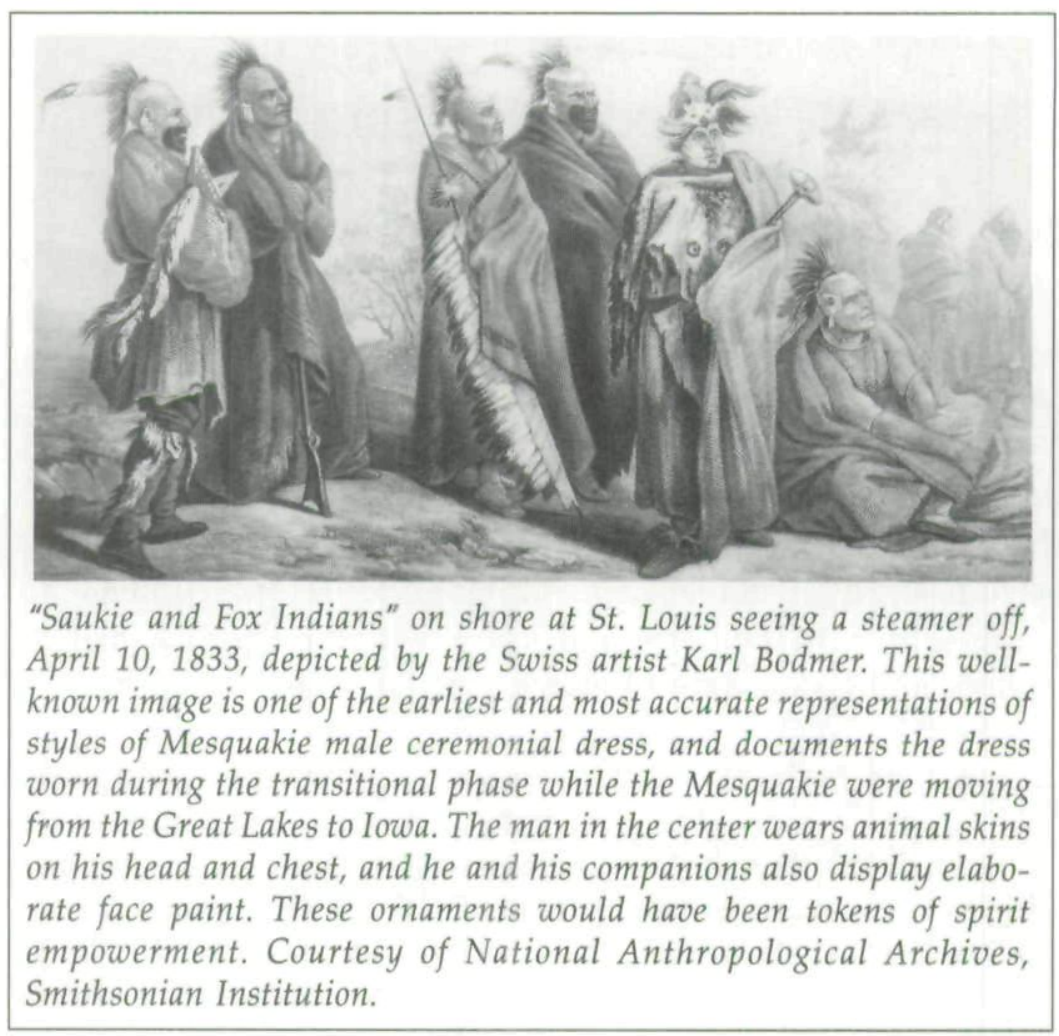

Mrs. Jameson's description exemplifies the fascination with which European and American observers have viewed Great Lakes Indian costume from the earliest years of contact down to the present. Like Mrs. Jameson, other Western observers have been struck by the strangeness and splendor of the costumes and by the high level of craftsmanship employed by their creators, but writers of a less subtle turn of mind have commonly used such words as gaudy, grotesque or barbaric to characterize elements of costume they did not understand and an aesthetic they could not appreciate. Convinced of the superiority of their own ways, these writers rarely stopped to question the deeper meanings of the colorful dress they recorded.

Despite their bias and superficiality, the textual and pictorial records of early European and American observers are necessary starting points for the study of pre-1850 Great Lakes 
Indian costume. Such records are essential complements of the surviving artifacts themselves, for the costume of Great Lakes Indians has defied the efforts of collectors over the centuries to capture it in its totality and display it under glass. Only fragments can usually be presented in museum displays or in publications - a pair of moccasins, a roach headdress, a beaded sash. Some of the most meaningful parts of the costume ensemble were ephemeral-hairstyles, face painting, and other forms of body decoration that cannot be collected or preserved but only documented with a greater or lesser degree of accuracy. The forms and motifs of some of the less ephemeral costume elements certainly can be appreciated on their own, but the significance of a costume is greater than the sum of its garments.

Costumes are made up of coverings and decoration applied to the human body; they both describe and elaborate the human form. Through costume human beings represent themselves to other people and, often, to supernatural forces. In every society costumes communicate things people wish others to know about themselves, such as gender, status, physical attractiveness, power, or stage of life. Within each individual society the particular messages being communicated reflect that society's beliefs about what makes a person feminine or masculine, beautiful or ugly, powerful or accomplished. ${ }^{2}$

However, the communicative range of costume goes beyond public statement, for dress is also the most personal of art forms. The historic costumes of the Great Lakes region offer good examples of how modes of costume and self-decoration made highly specific statements about the accumulated interior experience of an individual, and also about his or her psychological state at a particular moment. This dimension of personal experience is vital to the expressive energy that underlies the creation of a costume. Yet this private dimension usually remains unacknowledged precisely because such meanings

2. For interesting comparative discussions of the communicative role of costume in other cultural settings, see Margaret Blum Schevill, Costume as Communication (Seattle, 1986), and Robert Brain, The Decorated Body (New York, 1979). 
were the exclusive property of the wearers and creators of the costumes and were seldom divulged.

In many cases the specific details of iconographic explanation neither should nor can be known, but an awareness of the private significance of costume is important. Such awareness permits us to understand how the donning of a particular kind of costume could affect the wearer and selected beholders. In these intimate contexts self-adornment could be therapeutic, it could enhance self-confidence, and it could reaffirm critical social ties between two or more people.

In this essay I will examine the complex levels of meaning, both public and personal, that costume historically has had for native peoples in the Great Lakes region, and in particular for the Mesquakie of Iowa. The group of Mesquakie who settled in Iowa in the 1850 s were unusually successful in defending and preserving the Great Lakes cultural traditions they had brought with them from their homeland. Because of this unique history, ethnographers working with consultants at the Mesquakie settlement near Tama at the beginning of this century were able to record texts that yield particularly rich information about costume and its significance. These records are invaluable because they are direct statements by native people-in this case apparently subjected to relatively little editorial interference-and thus supply much insight about the integration of public ritual and private life that is missing from the descriptions by earlier European and American observers.

The ability of contemporary outsiders to appreciate the communicative force of Native American costume must always necessarily be limited, although the texts written by Europeans and Americans during the nineteenth century offer descriptive information and historical documentation that is not recorded elsewhere. This essay will focus on two early twentieth-century Mesquakie texts, one dictated by a woman and the other by a man, that provide insight into the significance of dress in individual Mesquakie lives. By privileging these native texts, and by giving equal weight to the statements of a woman and a man, we can achieve a greatly expanded appreciation of the scope and range of costume signification. These texts clarify the distinction between the pub- 
lic and private levels of communication through costume. They also allow us to examine the ways costume constructs and expresses gendered identity - the way it "talks about" maleness and femaleness in both sacred and human contexts. The availability of a female perspective is particularly valuable because of its relative rarity. The significance of fine articles of costume as the quintessential products of uniquely female competence is often overlooked, yet it is a critical aspect of the overall meaning of costume assemblages.

The relatively full descriptions of Mesquakie ritual and dress recorded in the Great Lakes region in the early nineteenth century by Morrell Marston, Thomas Forsyth, and others indicate that Mesquakie costume traditions were very similar to those of neighboring peoples such as the Potawatomi, Ojibwa, Ottawa, and Menominee. ${ }^{3}$ Because of this similarity, insights into Mesquakie concepts and usages will also contribute to the deeper understanding of historic costume usages throughout the Great Lakes region.

DESCRIPTIONS OF BODY-PAINTING PRACTICES dating from the early contact period illustrate clearly the way costume displays communicated, through a generally understood code, information about important events in an individual's life. Nicholas Perrot, writing about central Great Lakes people in the late seventeenth century, and Morrell Marston, discussing the Mesquakie at the beginning of the nineteenth century, both give detailed accounts showing the remarkable consistency and continuity of practices throughout the region. ${ }^{4}$ The use of color, for example, constituted a kind of visual language, clear and structurally consistent in its meaning. Red was associated with coporeality and with ideas of renewal of the flesh and life. Black signaled liminality and the sacred, spiritual world

3. The accounts by Marston, Forsyth, and several other observers are included in Emma Helen Blair, ed., The Indian Tribes of the Upper Mississippi Valley and Region of the Great Lakes, 2 vols. (1911; reprint ed., New York, 1969).

4. Marston notes that he has compared information with Forsyth, George Davenport, and Dr. Muir and that the "manners and customs of the Chippewa, Ottawa, and Pottawattamie nations ... are similar, if not the same as those of the Sauks, Foxes and Kickapoos." Blair, Indian Tribes, 2:153-54. 
associated with the separation of soul and body through fasting, encounters with manitos, and death. ${ }^{5}$

Thus red, in the form of ochre or vermilion, was worn at times of joy and affirmation. For example, Marston says that among the Mesquakie, "the young men and women, when they begin to think of marrying use vermillion." ${ }^{1}$ Painting with vermillion, too, was nearly always associated with putting on fine clothing and rich ornaments. At an adoption ceremony, when a new person was welcomed to fill the place of one who had died, Perrot tells us that the parents of the dead person who was being replaced "paint [the adopted child] with vermillion, and adorn him as handsomely as they can. ${ }^{7}$

Descriptions of the use of paint and fine clothing in preparing a person for death and burial are particularly striking. Perrot records that among the Ottawa and their neighbors when a person was at the point of death, "he is decked with all the ornaments owned by the family.... They dress his hair with red paint mixed with grease, and paint his body and his face red with vermilion; they put on him one of his handsomest shirts, if he has such, and he is clad with a jacket and a blanket, as richly as possible." Similarly, Marston reports that Mesquakie were buried in their best clothes. ${ }^{8}$ Here, too, the use of red paint and finery to adorn a dying or dead person expressed an affirmation of life, but of life after death. Things offered to the deceased would continue to be of use on the long journey to the afterworld.

5. I am grateful to Gaylord Torrence for his comments on the symbolic meanings of black. His findings in recent interviews with Mesquakie consultants further clarify many of the statements in the ethnohistorical literature. He was told, for example, that black paint "was worn by warriors who had been blessed with a vision and by men engaged in a sacred bear hunt," and that "individuals who had fasted could include the color black within the context of their pow wow costumes." Personal communication, Autumn 1989. See also Gaylord Torrence and Robert Hobbs, Art of the Red Earth People: The Mesquakie of Iowa (Iowa City, 1989), for extensive discussions of Mesquakie art in historical and cultural context. The overall conclusions presented here, however, are my own.

6. Blair, Indian Tribes, 2:236.

7. Ibid., 1:84-85.

8. Ibid., 1:78, 2:172-73. 
Black, in contrast, was worn in the face of danger or the threat of death, and it was associated with the absence of ornament and the poorest clothing. Men blackened their faces when preparing for war, when they fasted for a vision, when they were in mourning, or when setting out on the sacred activity of the bear hunt. Women, too, blackened themselves during their seclusion following the onset of first menses and during mourning. In keeping with a pattern common throughout the Great Lakes region, the Mesquakie thus humbled themselves in encounters with the spirit world in order to induce the spiritual beings to pity them and to bestow their blessings. Impoverished dress and blackness - the absence of light and of reflective, shiny materials-emphasized the neediness of human beings and their dependency on the good will of the spirit beings.

The alternation of black/raggedness and red/finery during the period of mourning provides the clearest example of the way costume symbolized personal distress or well-being. When they blackened their faces, both men and women also neglected personal grooming, particularly of the hair. Perrot's account of the behavior of widows is particularly vivid. A woman observes mourning, he writes, by "cutting off her hair, and not using any grease on it; she combs it as seldom as she possibly can, and it is always bristling; she also goes without vermilion, which she can no longer use on her face. Her clothing is but a wretched rag." At Manitoulin Island Mrs. Jameson noticed three men who stood out among the crowd because of their absence of fine costume. "There were three men with their faces blacked with grease and soot, their hair dishevelled, and their whole appearance studiously squalid and miserable: I was told they were in mourning for near relations." By contrast, the end of mourning and the resumption of normal life was signified by donning finery and red paint. At this moment, writes Perrot, a woman "again puts on handsome garments; she rubs vermilion on her hair and her face. ${ }^{\prime \prime 9}$ Costume, then, was a major signifier of important passages in life, of liminality and the achievement of a new status.

9. Ibid., 1:70, 71; Jameson, Winter Studies, 243. 
"THE AUTOBIOGRAPHY of a Fox Indian Woman" provides a remarkable account of the way these changes in costume marked the progressive life experience of one particular individual. The text recounts a woman's life history in her own words-her name is not given out of respect for her wishesand, according to Michelson, "The contents are the things which seemed of importance to herself," without any external prompting or editing."10 The use of autobiographies as ethnographic texts must always be approached with caution. However, Gretchen Bataille and Kathleen Mullen Sands, who have analyzed the "Autobiography of a Fox Woman" as part of a larger study of American Indian women's autobiographies, conclude that "certainly the narrative is valuable as ethnography, as a reflection of the day-to-day responsibilities of Mesquakie women, and as a record of the moral and domestic education of a young Indian girl."11

The "things of importance" recounted by the narrator are universal female experiences along the way from childhood to maturity. The author recounts her early education, the shock and confusion of puberty and adolescence, first courtship, marriage, childbirth, the death of a child, her unhappiness in marriage, divorce, loneliness, happy remarriage, widowhood and despair, and finally, a moderate contentment in a third and last marriage. The style of the narrative in its literal English translation is spare, almost terse.

10. The text "was obtained through Harry Lincoln in the summer of 1918. It was restored according to the phonetics of Dalottiwa, Harry Lincoln's wife, in the summer of $1920 \ldots$. . The English translation is based on a paraphrase written by Horace Poweshiek, supplemented and corrected by a grammatical analysis of the text by [Michelson]." Truman Michelson, "The Autobiography of a Fox Indian Woman," in Fortieth Annual Report of the Bureau of American Ethnology (Washington, DC, 1925), 295. Michelson's dominant interest in the text as a linguistic document provides indirect confirmation of the relative ethnographic reliability of the autobiography. The concern would seem to preclude much editorial tampering with the ethnographic descriptions of costume in which we are interested.

11. Gretchen M. Bataille and Kathleen Mullen Sands, American Indian Women: Telling Their Lives (Lincoln, NE, 1984), 38. The authors note gaps in the data provided by the text, particularly in the lack of any information about the subject's participation in the wider world of early twentiethcentury America. 
Punctuating the account, and marking each change in her status, each important moment of gladness or sorrow, is a dramatic change of costume. The narrative takes us back over the same kinds of events described by Perrot and Marston, but from the point of view of one individual's interior experience. Indeed, the restraint of the language and the knowledge that the things recounted were "the things that seemed important to herself" makes the ritual and aesthetic role of costume in Mesquakie life all the more striking. The alterations of grooming and adornment interrupt the narrative almost rhythmically, closing chapters in the narrator's life and opening new ones like refrains between the verses of a song.

The "Fox Woman's" first memory of such a change occurs at puberty. The narrator recalls her feelings of fear and pain during her seclusion. She was instructed in correct behavior but found everything strange and confusing. It was explained that she must not touch her own hair but let it hang loose and uncombed as a protection for herself and a warning of danger to others. Then her child's clothes were thrown away and new garments were given to her. This act, too, removed danger from herself and signaled to others that she was now a "new woman." 12

It is this section of the narrative that, according to Bataille and Sands, is probably most in need of correction because of the negative connotations Michelson's translation attaches to women's seclusion during puberty and the attendant rituals. "The Mesquakie attitude is a part of a lifeway that recognizes opposites as well as the reconciliation of those opposites," they note.

Rather than the manitous or gods "hating" the event, they took pity on her or felt sorry for her, knowing the loneliness of isolation and the fear associated with the first experience of womanhood. The matter-of-fact attitude of the mother contrasts with the honest fear expressed by the narrator when she first menstruates. The practice of isolation was necessary to keep the

12. Michelson, "Autobiography," 302-9. 
power contained. Adeline Wanatee [a contemporary Mesquakie consultant] interprets the experience simply: "Men have visions, women have children." 13

The blackened faces and the unkempt hair adopted by Mesquakie girls during this crucial passage in their lives is a spiritregarding usage exactly parallel to the costume adopted by young men during their vision quest at puberty.

The next important passage in the narrator's life came at age twenty, when she was about to marry. She was reclothed in new, rich garments by her chosen husband and his family.

Then he gave me his horse, and the clothing which he used at dances, his finery. ... Soon my mother-in-law came to summon me. "Go over there," my mother said to me. I departed. When I arrived there, "Right here," I was told. "Sit down," I was told. I sat down comfortably. Well, they began to clothe me in finery. I was clad all over in finery."14

Her marriage was followed by an event of great sadness, the death of her only child at the age of about two years. After the burial, following Mesquakie custom, she and her relatives

13. Bataille and Sands, American Indian Women, 36-37.

14. Michelson, "Autobiography," 314-15. Perrot describes an even more complex sequence of costume changes in which the bride's body acts as the vehicle by which the two families exchange gifts. "The new bride is dressed as handsomely as possible, and is accompanied by her mother-in-law, who points out to the girl the place near herself which she must occupy with her husband, who is then strolling in the village. When the bride is seated, the mother-in-law takes from her all the garments which she has on her person, and gives her others, also some goods which she carries to the girl. The latter then returns to her mother, who again strips her of all her finery, and receives from her all the goods that she has; then having dressed the girl for the last time, the mother sends her back to her husband's house, making her a present of some sacks of grain. Repeated visits of this sort are sometimes made very often; but when it is desired to end them the girl is dressed in ragged garments, and it is by this means that the marriage ceremonies are terminated." Blair, Indian Tribes, 1:68-69. See also the parallel description of a Winnebago bride transferring wealth not only in the form of finery, but also of horses, in Nancy Oestreich Lurie, Mountain Wolf Woman, Sister of Crashing Thunder: The Autobiography of a Winnebago Indian (Ann Arbor, MI, 1961), 30. 
began immediately to make "every kind of new finery," in a symbolic gesture of renewal. ${ }^{15}$

Her child's death was followed by divorce from her first husband and, after a time, by a new marriage to the man she had first loved but had not been permitted to marry. This second marriage opened the period of greatest happiness in the narrator's life. The intensity of her remembered joy breaks through the spareness of the prose. "So I loved him dearly," she remembers, "And after I married [him] I was so well." In her recollection her husband's goodness to her and his wish for her to enjoy her life takes the specific form of encouraging her to clothe herself in fine dress and to attend dances (a thing other husbands discouraged). In return, she says, "I continued to love him more and more." The emotional high point of the autobiography occurs in a passage describing this time.

"Well, I have surely found a man," I thought. "If this [man] were to cast me off to-day, I should tag after him anyhow," I thought. When he went to any place for a long time, I yearned for him. And I thought, "He has made me happy by treating me well. Then I began to make things for him, his finery, his moccasins, his leggings, his shirt, his garters, his cross-belt. After I had made finery of every kind for him, [I said], "These are what I have made for you as you have made me happy as long as I have lived with you, [and] because you have never made me angry in any way. 'You must dance vigorously,' I thought, that is why I made them for you." 16

It would be hard to find a more eloquent statement of the personal meanings that finely ornamented clothing could have for both maker and wearer. For the narrator, the creation of beautiful garments and ornaments was the most perfect medium for the expression of her deepest and most positive feelings for another human being. When worn, they must have signified for her husband, too, a high point of personal wellbeing. The private meanings of costumes are rarely recorded,

15. Michelson, "Autobiography, 320-21.

16. Ibid., 326-29. 


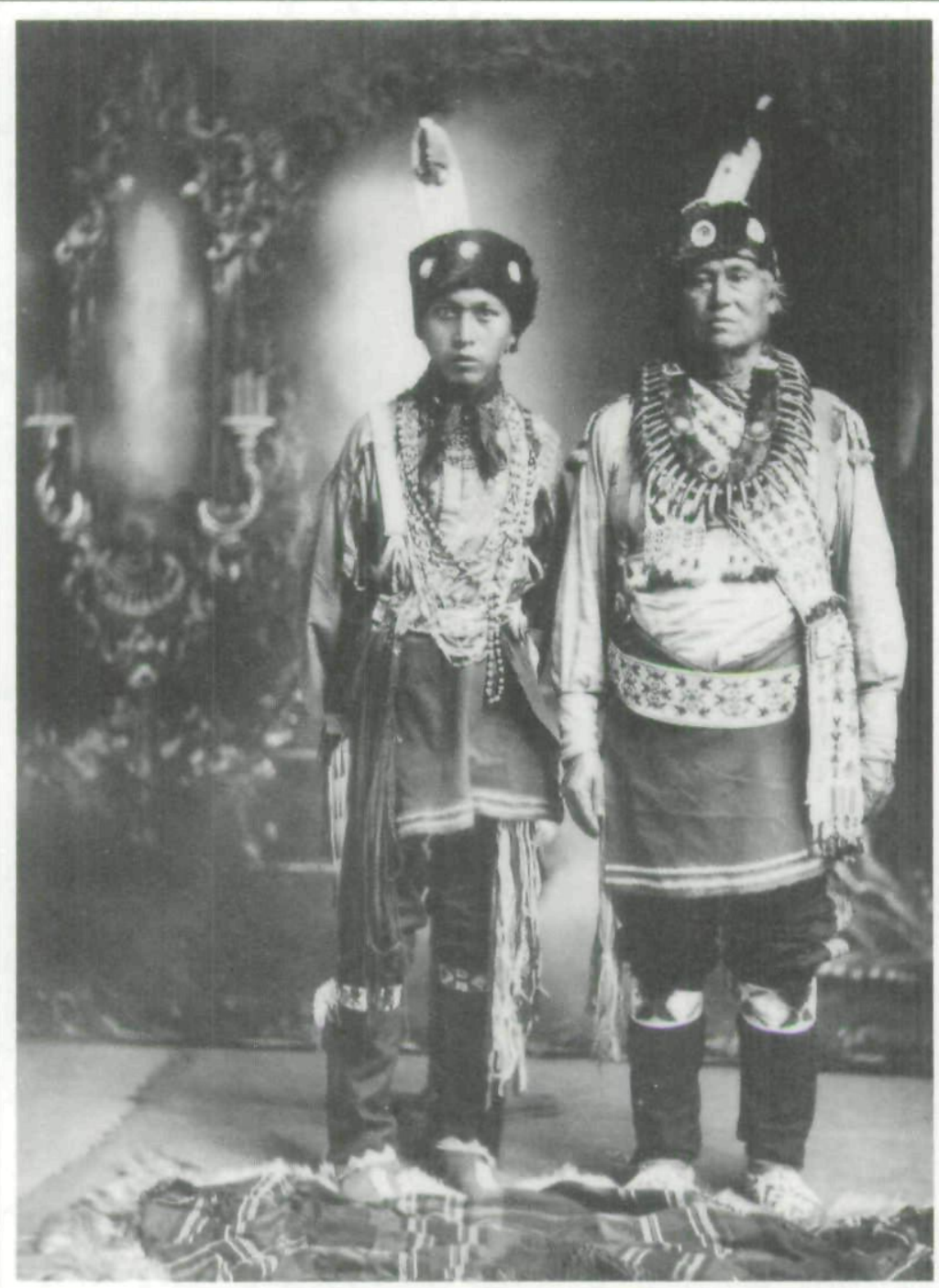

Po-kwi-ma-wa, b. 1888, on the left, and Ha-na-wo-wa-ta (James Onawat), $b .1837$, on the right. The photograph is part of a large collection assembled by Duren $H$. Ward in the summer of 1904 as part of his systematic documentation of Mesquakie life, and may have been taken in that year. It illustrates the kinds of garments lovingly made by Mesquakie women for the men of their families to wear on important occasions. Courtesy of Duren H. Ward Collection, State Historical Society of Iowa, Iowa City. 
but they are, in every culture, a part of the totality of meaning that is being expressed.

All too quickly the death of the narrator's husband ended this period of happiness. She expressed her grief by stripping away the clothing blessed by happiness.

Soon he fell ill. I felt very sorry for him. I felt terribly. Soon he became sicker and sicker. I cried in vain, as I felt so badly about him. And he died. Soon it was terrible for me. I undid my hair and loosened it.... And then the female relatives of my dead husband came to comb my hair. And they brought other garments for me to wear. I wore black clothing.

Grieving deeply, she continued to wear these clothes until released from the death ceremonies by an adoption feast. Then she was told once more to take off her mourning clothes. "Then they began to clothe me in fresh clothes, and my hair was combed and my face washed. And then I was told, 'Well, do not take off your [clothing]. For [now] you are to be clad like this. You may begin to wear finery. You may go and do whatever you please.'"17

Although many of the customs described in the "Autobiography" are recorded in other places, the narrative provides a rare opportunity to appreciate the way the ritual changes of costume facilitated the individual's psychological integration of crises in life. We are led to understand changes of costume as a cognitive set, comforting and reassuring the narrator during times of difficulty or newness by virtue of their structural regularities and symmetries. The text brings to life the customs recorded by travelers and ethnographers.

Another theme that emerges from a reading of the "Autobiography" is that fine clothes are made for dancing, and that costumes and dancing are, in fact, necessary complements of each other. "You must dance vigorously," the narrator tells her husband when she presents him with the garments she has made. "That is why I made them for you." ${ }^{18}$ Not only the ritual, but the aesthetic of costume depends on the animation,

17. Ibid., 328-33.

18. Ibid., 328-29. 


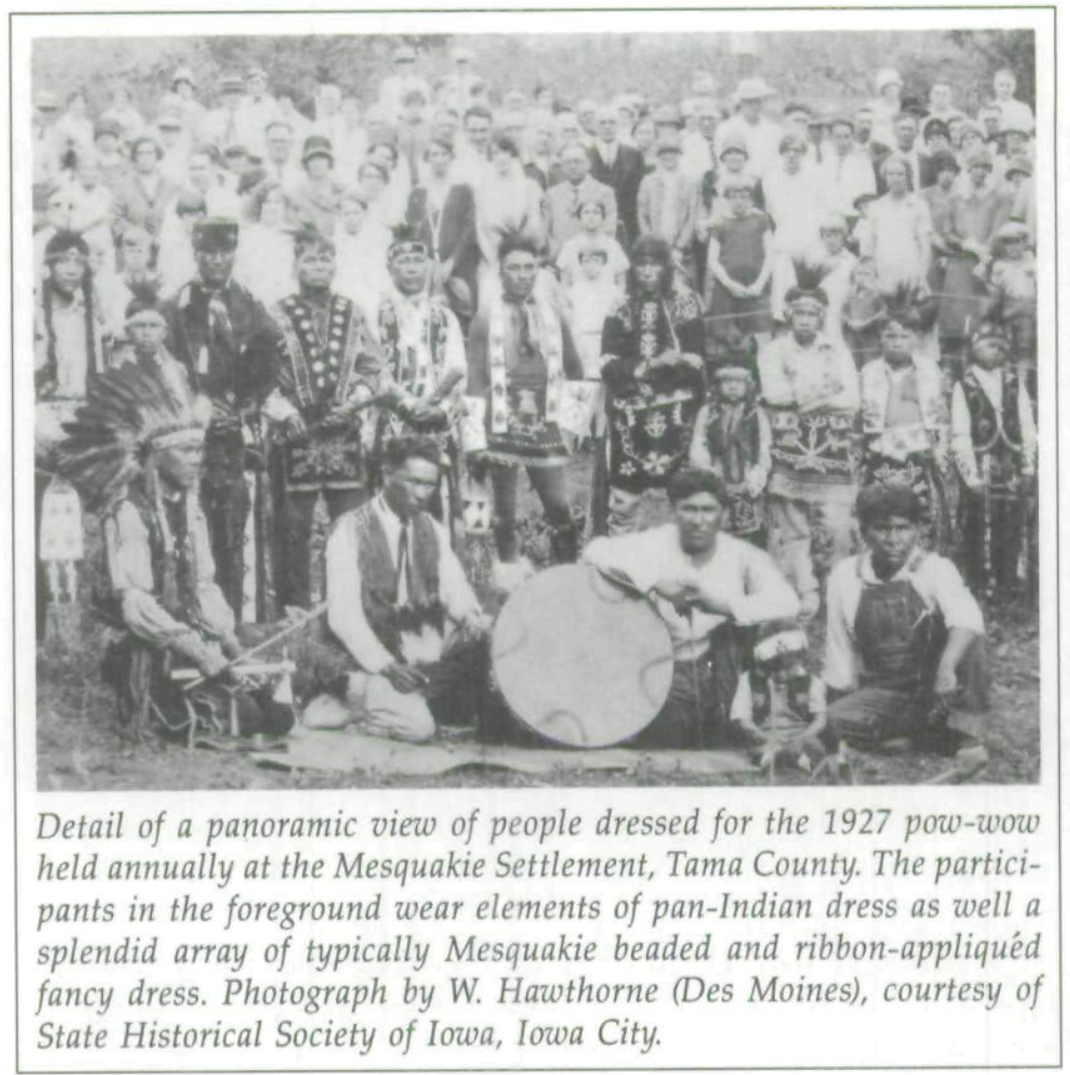

rhythmic movement, and music of the dance. The choices made by the makers of costume for particular textures, colors, and decorative elements are determined not only by their visual qualities but also by their kinetic and auditory qualities. One has to hear the tinklers on moccasins as well as see them, to see fringes and feathers sway and nod, and silver, beads, and ribbon shimmer in shifting light and shadow.

MOST of the written and visual descriptions of costume from the early contact period depict costumes worn at dances and ceremonies associated with warfare. ${ }^{19}$ Such dances called for

19. Similarly, at the mock battles played out at races and lacrosse games, men wore full paint, finery, and ornaments. We are told, furthermore, that the two moities of the Mesquakie could be distinguished on such occasions by color; 
particularly elaborate body painting and dress on the part of both men and women. Marston reports that when Mesquakie warriors returned from a successful campaign, "The party will halt several miles from a village and send a messenger to inform the nation of their success, and of the time that they intend to enter the village; when all the female friends of the party will dress themselves in their best attire and go out to meet them; on their arrival it is the privilege of these women to take from them all their blankets, trinkets, etc., that they may possess; the whole party then paint themselves and approach the village." 20

At Macinaw in 1837 a group of warriors held a dance in honor of Mrs. Jameson, who left us a vivid description of their dress.

No two were alike. One man wore three or four heads of hair, composed of the manes and tails of animals; another wore a pair of deer's horns; another was coiffé with the skin and feathers of a crane or some such bird-its long bill projecting from his forehead; another had the shell of a small turtle suspended from his back, and dangling behind; another used the skin of a polecat for the same purpose. One had painted his right leg with red bars, and his left leg with green lines; particoloured eyes and faces, green noses and blue chins, or vice versa, were general. ${ }^{21}$

Despite the detail of her account, Mrs. Jameson writes of the warriors' costumes as if they were merely fashions, comparing the "dandyism" of Potawatomi warriors to that of Bond Street beaus. ${ }^{22}$ The same is often true of another recorder of these costumes, George Catlin, whose vivid portraits of Great Lakes Indians are contemporary with Mrs. Jameson's writings and depict many of the same kinds of dress. In his diary Catlin often asserts the strict accuracy of his portraits in depicting every

one used black paint and the other white. Marston, in Blair, Indian Tribes, 2:157, 194.

20. Blair, Indian Tribes, 2:158.

21. Jameson, Winter Studies, 191.

22. "The dandyism of some of these Pottawattomie warriors is inexpressibly amusing and grotesque; I defy all Regent Street and Bond Street to go beyond them in the exhibition of self-decoration and self-complacency." Ibid., 169. 
feather and quill correctly. If we read between the lines, we gather that his sitters were insistent on the careful recording of many details. Catlin usually attributes their concern to "vanity." Like Mrs. Jameson, he seems to regard the rich variety of dress he painted as so many fashions.

His comments on the hairstyles worn by Mesquakie men and those of neighboring nations are an exception to this tendency. It was usual to shave the head, Catlin wrote, except for the area at the crown to which was attached

a beautiful crest made of the hair of the deer's tail (dyed red) and horsehair, and oftentimes surmounted with the war-eagle's quill. In the centre of the patch of hair, which I said was left of a couple of inches in length, is preserved a small lock, which is never cut, but cultivated to the greatest length possible, and uniformly kept in braid, and passed through a piece of curiously carved bone; which lies in the centre of the crest, and spreads it out to its uniform shape, which they study with great care to preserve.... This little braid is called in these tribes, the 'scalp-lock,' and is scrupulously preserved in this way, and offered to their enemy if they can get it, as a trophy; which it seems in all tribes they are anxious to yield to their conquerors, in case they are killed in battle; and which it would be considered cowardly and disgraceful for a warrior to shave off, leaving nothing for his enemy to grasp for, when he falls into his hands in the events of battle. ${ }^{23}$

In this instance, then, Catlin recognized that this hairstyle was not just a fashion but an important statement about the wearer's courage in war.

Indeed, costumes often communicated further information along these lines. As noted by Mrs. Jameson and many others, eagle feathers signified successful attacks in war. Furthermore, when a warrior captured the scalp lock of an enemy, it was frequently attached to his shirt or belt. The messages of the hairstyle and the trophy in such cases were complimentary: one expressed a challenge to the enemy and the other victory over him. ${ }^{24}$ It is not surprising that both Mrs. Jameson and Catlin

23. George Catlin, Letters and Notes on the Manners, Customs, and Condition of the North American Indians, 2 vols. (Minneapolis, 1841), 2:24.

24. The highly specific war-related symbolism of men's hairstyles also 
understood this type of significance, for they, too, came from societies in which war was a central institution and whose soldiers paraded the signs of their valor on their dress.

The elaborate patterns of body painting and the ornaments of bird and animal skins recorded by the early observers were even more important elements of warriors' ceremonial dress, but they were charged with sacred meanings beyond the comprehension of Europeans. ${ }^{25}$ To understand the kinds of meanings these costume elements communicated we must turn to the second of the two Mesquakie texts mentioned earlier. This text relates the origin of fasting for power and of the first Mesquakie sacred bundle. It was dictated to M. R. Harrington at Cushing, Oklahoma, by Mecabekwa at the beginning of this century. ${ }^{26}$

The narrative tells of a young man who later receives the name Pitockah, or Pitoski. Poor and in a state of hopelessness, "he painted himself [black] and made up his mind that he would go out and starve." He was saved from death by the Great Manito, and blessed with "power and strength." A transformation of his appearance occurred as a result, for the manito told his grieving parents, "do not cry any more, as the day is coming when you will see him face to face. You will see what changes I have made in his body and features." During his quest Pitoski received a series of revelations in which he was instructed by the manito to take the skin from certain parts of a buffalo, to split and dry the skin of a raven, and to go to particu-

explains why they changed so rapidly when warfare ceased in the reservation period.

25. In addition to the coiffures, body painting, and ornaments described by nineteenth-century observers, seventeenth- and eighteenth-century observers of Great Lakes Indians also describe elaborate traditions of tattooing. The images were derived from an individual's visionary experience and included representations of guardian spirits. The practice of tattooing seems to have become less common in the course of the eighteenth century and to have largely disappeared by the early 1800 s, although one fur trader wrote in 1809 that many Saulteaux had tattoos of "the sun, stars, eagles, serpent \&c. in the choice of which they are generally led by the virtue of some extraordinary dream." Peter Grant, in L. R. Masson, Bourgeois de la Compagnie du Nord Ouest, 2 vols. (New York, 1960), 2:317.

26. M. R. Harrington, "Sacred Bundles of the Sac and Fox Indians," University [of Pennsylvania] Museum Anthropological Publications 4 (1914), 122-250. 
lar places to collect red and blue paint. He also encountered a spirit hawk and a spirit owl and acquired body parts of each, which gave him power in war. "In war time," the manito told him, "you will strike the first, and kill the first enemy." He was also told to capture and take for power the skin of a black wolf. The climactic moment of Pitoski's vision was an encounter with Thunders who gave him a powerful medicine, a round bone object that "turns blue in the winter, and is said to represent the sky. ... This is the strong power of all the Thunders. It was taken from the sky, and is very powerful. ... In war you will use this, so the enemy cannot defeat you." 27

Pitoski added these sacred and powerful things to the bundle he had been given, but as he returned home he wondered, "How shall I know what to do with these things?" The Great Manito answered, "Take up that raven first, and lay it upon the wolf hide; then split it and prepare it to use as a head band." Pitoski was told to make a necklace and arm bands of the buffalo's skin and to tie bundles of medicine to it. Finally, he was instructed to "split the black wolf hide so that you can wear it with its head upon your breast and its rear parts and tail hanging down your back." Later, in a battle, Pitoski wore these things and they lent him the power to "travel like the wind, or as a bull-snake slips through the grass." The black wolf's hide endowed him with the "wolf's cunning, speed and endurance," and enabled him "to travel at night like a wolf." 28

Pitoski fasted a second time. This time the manito gave him black and red paint and precise instructions for their use. "Paint yourself in this way," he was told: "a zigzag line over the right eye, then a cross made of double lines on both arms, the left breast and the stomach, and a cross of single zigzag lines on the legs above the knees, and the calves of the legs the same; then a round spot on the forehead, on the palms of your hands, and on the inside of your feet just below the instep." 29 The paint was not just pigment, it was also medicine. Applied in the correct patterns, it empowered the wearer. Applied to his war whistle and weapons, the paint ensured that his enemies would die.

27. Ibid., 136-43.

28. Ibid., $144-47$.

29. Ibid., 152. 
The narrative also makes clear that certain power objects should be worn in full view. Pitoski's father told him that he must wear his whistle around his neck, "so everyone may know you have had power given to you." 30

The concept implicit in this statement underlies much male ceremonial costume. The headbands and neckbands, and probably many of the shell gorgets and other ornaments worn by warriors, were statements that the wearer had been given power. But the members of the community "read" the power objects attached to costumes on several discrete levels. The animal skin tokens constituted a comprehensible symbolic language analogous to the use of color. They expressed the nature of the powers conferred referentially through established analogies to the characteristics of various animal species, characteristics that were intimately known to members of hunting communities. The skin of a hawk signified deadly accuracy in attack; the skin of a wolf suggested speed and cunning; and that of a loon, extraordinary powers of sight.

The meaning of another class of power objects, however, did not signify meaning in the same way. The amulets attached to costume resulted from private and restricted knowledge of ritual formulas and medicines. By attaching such objects to his costume the wearer signified his possession of power, but the specific nature of the power would not have been public knowledge. In some ways, we can imagine, this power would have been all the more impressive for the mystery that surrounded it. The blessing of the spirits for success in war was thus an important theme communicated by men's ceremonial clothing of the early contact period.

In addition to elaborate body paint and a variety of tokens and ornaments, however, men also wore sets of beautifully decorated garments. Some of the patterns used in embroidering and appliquéing the blankets, leggings, and moccasins may have made reference to some of the same ideas. Motifs such as zigzag and meander lines, which occur as power lines in representations of Thunderers and Underwater Panthers, may, on clothing, also carry significations of power bestowed on

30. Ibid., 154 . 
humans by the manitos. ${ }^{31}$ There is also evidence that many apparently decorative motifs, whether geometric, floral, or representational, were directly inspired by women's visionary experiences, although most of the literature on Great Lakes art and material culture does not recognize them as such. According to this interpretation, patterned and ornamented clothing would have conveyed still further references to human experience of the animate powers in nature. ${ }^{32}$

WHETHER OR NOT such specific iconographic readings are valid, the ethnohistoric documents suggest that finely decorated clothing did have a further dimension of meaning for Mesquakie and other Great Lakes peoples, one that is not often discussed. This further dimension has already been introduced into this discussion by a passage cited earlier from "The Autobiography of a Fox Woman." This is the passage in which the narrator, during a period of great happiness in her life, made for her husband "finery of every kind," conferring on him the most valuable gift it was in her power to give.

In any society gifts of this kind retain enhanced, though private, meaning for the wearer. But among the peoples of the Great Lakes region, the ability to make finely decorated clothing resonated in a particular way in terms of the designated roles and abilities of men and of women. Access to the raw materials, whether hide and porcupine quills or trade cloth and beads, depended on the hunting skills and labor of men. The manufacture of clothing, on the other hand, was the work of women. And the artistry and skill needed to make finery represented the apogee of a woman's maturity and competence.

In the early nineteenth century Marston wrote of the Mesquakie that "the girls as a matter of course are under the direction of their mother, and she will show them how to make moggazins [sic], leggins, mats, etc. She is very particular to keep

31. Ruth B. Phillips, Patterns of Power: The Jasper Grant Collection and Great Lakes Indian Art of the Early Nineteenth Century (Kleinburg, Ontario, 1984), 29-30.

32. I have discussed women's visions as sources of textile design and decoration in "Great Lakes Textiles: Meaning and Value in Women's Art," in On the Border: Native American Weaving of the Great Lakes and Prairie (Moorhead, $\mathrm{MN}, 1990)$. 
them continually employed, so that they may have the reputation of being industrious girls, and therefore the more acceptable or more sought after by the young men." ${ }^{\text {"3 }}$ Again, "The Autobiography of a Fox Woman" - together with other autobiographical studies of Great Lakes women-offers both confirmation of this observation and a deeper understanding of its implications. ${ }^{34}$

The narrative contains within it an account of the author's progressive mastery of sewing skills as she matured from child to woman. The stages of her training were carefully timed by her mother. The first task to which she was set, as a child of seven, was making clothes for her dolls. Indeed, she remarks, "that is why one has dolls, namely, to make everything for them-their clothing and moccasins." At eleven her mother began teaching her to weave mats, and at twelve to make moccasins and yarn belts. She was made to practice each new craft until she achieved competence; only then was she taught a more complex one. ${ }^{35}$

All along her mother told her that these skills were necessary, so that when she grew up she would be able to take care of herself, and that she was being set to do the work so that she would grow up to be a virtuous and productive woman. In the liminal, impressionable state of fasting and puberty seclusion, her grandmother reinforced the lesson. "'My grandchild,' she would say to me, 'soon I shall tell you how to live an upright life. ... Now as for your mother, I began giving her instructions before she was grown up, every time I saw her. . . That is why she knows how to make things which belong to the work of us women. If you observe the way your mother makes anything, you would do well, my grandchild.'"36

33. Blair, Indian Tribes, 2:165.

34. The most important comparable autobiographical accounts are given in Ruth Landes, The Ojibwa Woman (New York, 1938), and Lurie, Mountain Wolf Woman. All three agree to a remarkable extent on the ideal accomplishments of women and contain similar discussions of the narrators' training as young girls.

35. Michelson, "Autobiography," 296-303.

36. Ibid., 305. 
The pace of instruction increased after this-" and I began to be told to make something more than ever," the narrator recalls. She learned to make baskets, and then, at fifteen, the highest of accomplishments were added to her repertoire. "You may now try to sew bead and appliqué ribbon work. If you know how to sew you are to make things to wear when you dance. If it is known that you can already sew, [people] will hire you. Not merely that. You will be paid.'" Her mother stressed the value of having skills that would bring income, but they were hard to achieve.

Then indeed I began to practice sewing. It took me a long time to sew well. It [must have] taken me two years to sew well. From then I was always making something.

I was sixteen years old when we were making mats in the summer. In the winter we were making sacks and yarn belts, [and] we were sewing appliqué ribbon work and bead work. Behold, it was true that I was constantly asked [to make] something, [and] I would be paid.

Now, having learned all the skills suitable to an adult woman, she began to be courted. ${ }^{37}$

The two strands of the narrative, the reclothings that occur at times of change and the industrious making of clothing and ornaments, converge in the passage already cited, when out of her great happiness the narrator made a set of finery for her husband. In this text the most finished and beautiful products of women's work are inextricably tied to the notion of the virtuous woman, for it is only through conscientious acquisition of the skills prescribed for women that she acquires the ability to make them. The special resonance of fine clothes is thus moral and ethical as well as aesthetic. This, too, is an association that should not be overlooked in the consideration of the meanings of clothing.

WILSON DUFF wrote that "meaning" in art can be defined as the answers to two questions: "what things is it about?" and

37. Ibid., 309. 


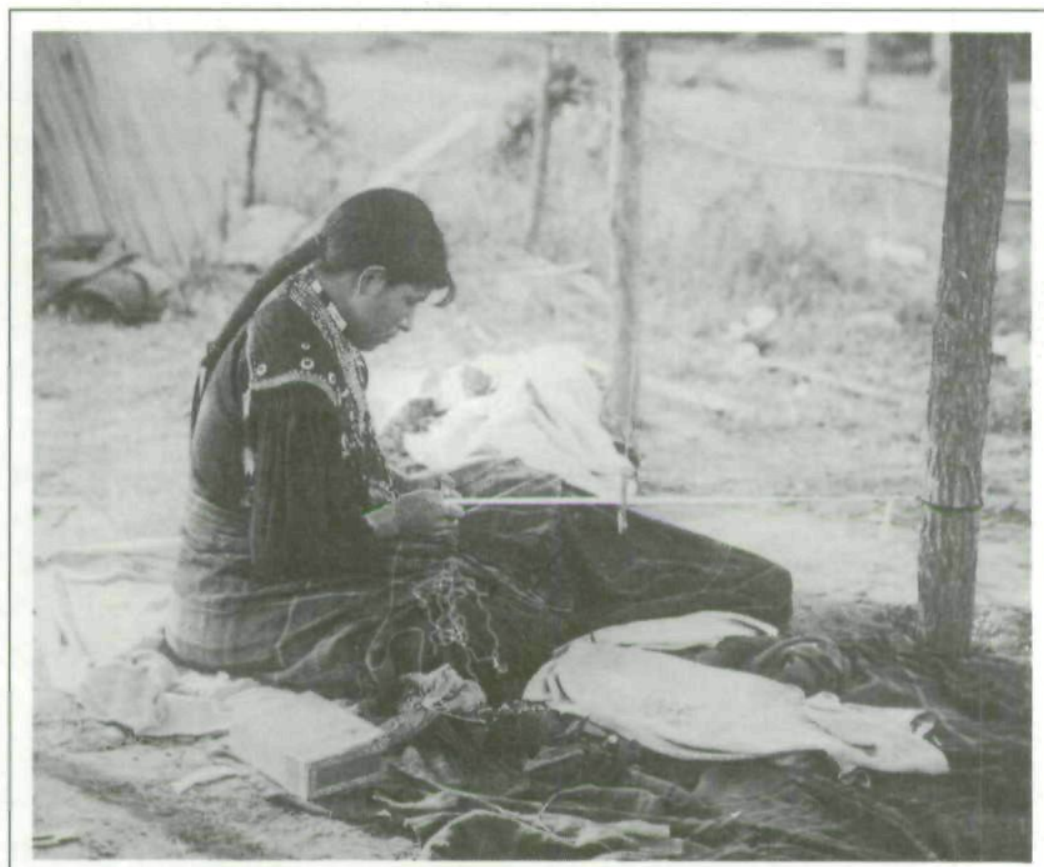

An Iowa Mesquakie woman doing beadwork. The photograph, taken in 1898 at the Trans-Mississippi Exposition and Indian Congress, is typical of the staged scenes created for living displays which were also popular with both ethnographic and commercial photographers around the turn of the century. The outdoor setting and fancy dress worn by the subject probably reflect the requirements of the photographer rather than the actual settings of such activities. Photograph by F. A. Rinehart (Omaha), courtesy of State Historical Society of Iowa, Iowa City.

"what is it saying about them?"38 We have seen that historic Great Lakes costumes speak about two kinds of blessings. Body decoration and a wide range of ornaments signified the direct blessings of guardian spirits. Decorated garments signified another kind of blessing, one that resulted from the cultivation and correct application of specifically human abilities. Mesquakie costumes, like those of other Great Lakes peoples, thus refer to the world of spirits on the one hand, and to the world of men and women on the other.

38. Wilson Duff, "The World Is as Sharp as a Knife," in Roy L. Carlson, ed., Indian Art Traditions of the Northwest Coast (Burnaby, B.C., 1976), 47. 
Nineteenth-century European and American accounts of Native American life usually represented the sacred and the secular and the male and the female as mutually exclusive dualities. They also aligned the sacred with the male and the secular with the female. In so doing, early observers were representing Native Americans in their own image, reflecting the extreme separation of male and female and sacred and secular that characterized the Victorian and Edwardian eras. Although we must continue to rely on the textual and pictorial observations of our forebears, this reliance carries with it an obligation to understand the distortions in the images. The testimony of Native Americans can act as a corrective, despite the barriers raised by translation into English and the conventions of ethnographic transcription.

Historically, costume has been a primary form of aesthetic expression among Great Lakes peoples, and thus embodies a discourse about such central issues as the interactions of people with nonhuman forces and of men and women with each other. Mesquakie statements about dress permit a glimpse of a different, more fluid way of conceptualizing these categories and their interrelationships. In the creation of costume, male and female skills and powers must combine; in the wearing of costume, men and women obey common conventions dictated primarily by an individual's psychosocial state rather than by gender. Both men and women engaged in a quest for extrahuman power, and both men and women wore the proofs of success in this endeavor in the form of rich clothing. Similarly, both sexes stripped away these outer markers of confidence and competence when seeking the blessing of spiritual powers and at times of bereavement.

A third experiential realm that is usually represented dichotomously by Westerners, the public and the private, is also bridged in Mesquakie costume display. Historic Great Lakes costume traditions proclaim publicly the fruitful interdependence of men and women, and of people and nonhuman beings, while simultaneously speaking intimately of personal psychic and emotional states. The personal could resonate in a private sphere contained within the public arena. Recognition of these broad contexts of meaning in Great Lakes costume 
enables not only the appreciation of surviving artifacts that once formed part of an individual costume assemblage, but also of the contemporary ceremonial dress that continues to be inspired by these rich historic traditions.

Editor's Note: Readers interested in seeing more illustrations of Mesquakie costume than can be presented here should refer to Gaylord Torrence and Robert Hobbs, Art of the Red Earth People: The Mesquakie of Iowa (Iowa City, 1989), and Ginalie Swaim, "Clothe Yourself in Fine Apparel': Mesquakie Costume in Word, Image, and Artifact," Palimpsest 72 (Summer 1991), 70-82. Art of the Red Earth People is a catalog prepared to accompany an exhibition of Mesquakie art at the University of Iowa Museum of Art. The Palimpsest article is a photo essay that draws heavily on the interpretations presented in Professor Phillips's article. 
Copyright of Annals of Iowa is the property of State of Iowa, by \& through the State Historical Society of Iowa and its content may not be copied or emailed to multiple sites or posted to a listserv without the copyright holder's express written permission. However, users may print, download, or email articles for individual use. 